\title{
State Theory of Marxism and Its Contemporary Value
}

\author{
Xue Zhihan ${ }^{1}$ \\ ${ }^{1}$ School of Marxism, Qufu Normal University,Qufu, Jining, Shandong, China, 273100
}

Keywords: Marxism, state theory, development, value

\begin{abstract}
The state theory of Marxism firstly clarified the origin, essence, nature, type and functions. It has become a guide for people to understand the national issue correctly. Under the new historical conditions, the proletarian state should further deepen the understanding of the basic connotation of the state theory of Marxism and its contemporary valuein order to adhere to the dictatorship of the proletariat and improve the proletarian dictatorship better.
\end{abstract}

\section{State Theory of Marxism}

"State" is one of the most commonly used words. However, what is the state? What are the concept, essence and functions of the state? What are the differences and relationship between nation and society? We should firstly clarify the scientific theory of the state.

State Theory. The state theory is a system of theories, views and ideas of the country. The object of the state theory is the state. It is on the concept, essence, function, the forms and the types of the state, the structure of the state, democracy and dictatorship, the government and people of the relationship, the state and revolution, the strategy, national development of the law of state theory. Since the emergence of the state, it has been gradually developed on the theory and theory of the state. Different ruling classes made their own different national theory in different historical periods. National theory and the state system, has its history of development, has its development law. One kind of state theory, which denies the theory of another state, is often a kind of dialectical negation, which inherits the positive factors of the former. We should analyze Marx doctrinefrom the perspective of national theory because the Marx doctrine is the most scientific, the most correctand the most revolutionary theory of the state. Only we have a thorough understanding of this theory, and use it to arm their minds, can we not be lost in the process of building socialist democracy.

Formation of State Theory of Marxism. In 1842, the first treatise of Marx named "on Pseudo-freedom" recently has talked about national issues. He believed that "the state should be the political legitimacy of the rational reality". In 1842, Marx served as the editor in chief of the Rhine newspaper, directly involved in the struggle against the government of the government, prompting Marx to study more extensively the social problems, especially the economic problems. This stage of political struggle and economic problems of the study, the establishment of the Marx's view of the state has played an important role in. Marx at this time has seen the relationship between the law and the phenomenon of life in the country is not based on the German or rational, but rather than a person's will for the transfer of the objective relationship. Marx wrote in 1844, "economic and Philosophical Manuscripts" mentioned in the state is the production of special way, to obey the general law of production. The Communist Manifesto was published in 1848, which marked the birth of scientific socialism and the birth of Marxism. Likewise, it also marked the birth of the state theory of the Marxism. 


\section{Content of the State Theory of Marxism}

The state theory of Marxism is based on the scientific view of the state of science. Dialectical materialism and historical materialism are the theoretical basis of his theory.

Content of the State Theory of Marx. The theory of Marx has formed a multi content, multi field coverage thinking in the profound development process. The state theory of the establishment of proletarian state (the socialist state) is one of the most important aspects in the theory.

The state has not been the original meaning of the state. The proletarian revolution shatters the bourgeois state machine and establishesthe proletarian state, but it is still a public power. The construction of public power is not only the military government, prisons and other enforcement agencies, and on this level it is still an instrument of oppression, the country is still the country. But because it is not the majority of the residents to suppress the commune, but few residents (exploiters); the bourgeois state machine has been broken; residents have own power special power instead of repression. All of this is not the original meaning of the country. Marx in this have been clearly explained due to the suppression of objects into the past a few of the exploiters, residents came to repression, instead of people's armed forces of the exploiting classes in the past, which with the original exploiting class repression exploited class countries are essentially different. So, Marx said he was not the original meaning of the country. The proletarian state is proletarian dictatorship and the unity of proletarian democracy, is a new country. The essence of Marx's country is not confined to the dictatorship of the proletariat, including proletarian democracy. Lenin had clearly said: "the dictatorship of the proletariat is the destruction of bourgeois democracy and the establishment of proletarian democracy." The proletarian state can't avoid the new democratic state and the new state of dictatorship." Lenin explicitly combined the dictatorship of the proletariat and the proletarian democracy together to reveal the essence of the proletarian state.In 1850, Marx in the 1848 to 1850 French class struggle mentioned“a constitutional republic is a dictatorship of the implementation of joint exploitation of farmers; social democracy red republic of China is a dictatorship of the allies of the farmers”.This is the first time that Marx has discussed the national form of the proletariat. After the Paris Commune Revolution, Engels and Marx had a more clear exposition: "it is in essence the government of the working class".

Development of the State Theory of Marx by Lenin. The Bolshevik Party headed by Leninled the Russian people to the victory of the October revolution. In the constant struggle with the enemy, Lenin not only defended the Marx doctrine of the state theory, but also combined with historical conditions and practical experience, and constantly developed the theory of the Marx doctrine. First, there is no "pure" democracy. Lenin believes that democracy is to acknowledge that the majority, a class to another class, some citizens have the system in another part of the civil violence organization. So, when we talk about democracy, we should not forget the class nature of democracy. Second, the exploited and the exploiters are never equal. Lenin pointed out in a class to exploit all possibilities of another class not completely eliminated before may not have a real sense of equality. Properties of regime decided proletarian regime must have its own state machine, which is political stability based, but that for the oppressed there is no democracy. Therefore, exploiters and exploited people are not equal.

Development of the State Theory of Marx by Mao Zedong. The state theory of Marxism was introduced with Marxism and Leninism into China. As the Communist Party of China to establish the ideological preparation, Marx's theory of state and the Chinese revolution continue to combine. At the beginning of the founding of the Communist Party of China, first congress programmer formulation has made it clear that to the national theory of Marxism as a guide to Chinese revolution. Combining the Lenin's thought of the state, the Communist Party of China has become a 
major feature of Marx's theory of state. Mao Zedong and other members of the Communist Party of China development another feature of the Marxist theory of the state is. It is not only a combination of views of Marx and Lenin's theory of the state, and further combined with the practice of the Chinese revolution, new problems, solve new problems, to the development of Marxist theory of the state. "Selected works of Mao Zedong" begins with the first article is "analysis of the classes in Chinese society", Mao Zedong put Marxism class analysis method, analysis of China's social from all walks of life, and to establish the relationship between friend and foe, and pointed out that the national bourgeoisie in China won't work. The strategic model of the countryside surrounding the city, this theory is his great contribution to the theory of the Marx doctrine. Therefore, Mao Zedong not only simply used the Marxist theory, but also combined it with the experience of the Chinese revolution. He constantly summed up the experiences andguided the development of the Chinese revolution.

\section{Contemporary Value of the State Theory of Marxism}

Futures of New State. The Marx doctrine emphasizes the unity of content and form a truly democratic society in the future. That is to say, the working people should be the masters. We are still in the primary stage of socialism. It is an important part of the public economy and the non-public economy to socialist market economy. It is an important foundation for China's economic and social development. We must unswervingly consolidate and develop the public sector of the economy, and adhere to the dominant position of the public ownership, play a leading role in the state economy, which provide a solid foundation for the people are the masters of the country. Through the establishment of a new national system, the proletariat obtained its own economic and labor liberation. Only the broad masses of the people to achieve economic and labor liberation, in order to fully realize the Democratic system. All civil servants of the Paris commune, regardless of rank, are paid the same wage. The highest salary limit setting, to determine the actual workers administrative duties, can effectively prevent the corruption of government officials. Government officials lost the will of the pursuit of careerism, and then the country will become pure. It is beneficial to the people.

Functions of Socialist State should be reinforced, not be weakened. In the face of today's international some strong capital strength and the increasingly complex international situation, in the face of the growing military strength and scientific and technological strength of the hegemoniccountries, the socialist countries must improve its own strength and the sovereignty and security system to safeguard ability.

To enhance the power of socialist countries is to strengthen the construction of the state system of people's democratic dictatorship, which is the theoretical system ofChina's Characteristic Socialismhas been emphasized. The use of the power of the people's democratic dictatorship can effectively protect the fundamental interests of the country, which is just the right thing to do. Deng Xiaoping made it clear that we should use the power of the people's democratic dictatorship to consolidate the people's political power. The use of the power of the people's democratic dictatorship can effectively protect the fundamental interests of the people. In the west, the bourgeoisie ruled for several hundred years, they know the importance of the function of the state dictatorship, have a firm, never give up and relax. Western governments, courts, police, military, but also to the use of legal, administrative and advanced technical means to perform the functions of the dictatorship. To strengthen the people's democratic dictatorship is the inherent requirement of building a socialist political civilization. In 2014 September 5,Xi Jinping clearly pointed out: China implemented under the leadership of the working class and based on the alliance of workers and 
peasants as the constitution as the foundation of the people's democratic dictatorship, the implementation of the regime of the people's Congress system, the implementation of multi-party cooperation and political consultation system under the leadership of the Communist Party of China, the implementation of the system of regional ethnic autonomy, the implementation of grass-roots mass self-government system, with distinct Chinese characteristics.

To strengthen the function of the socialist state, we must promote the modernization of national governance system and governance capability. Promoting the modernization of national governance systems and governance capabilityand the people's democratic dictatorship are not conflicting. The governance modernization cannot replace the people's democratic dictatorship. On the contrary, the modernization of national governance must be firmly established on the basis of the people's democratic dictatorship system. On this basis, the government should do the following work well.First, we should promote the process of governing the country by law to make sure that the country's governance is firmly established on the basis of the rule of law.

Second, we should vigorously carry forward and cultivate the socialist core values to promote the modernization of national governance systems and governance capability and the value system can fully reflects the Chinese characteristics, the national characteristics and the times characteristics. Third, we should also improve the discipline inspection and supervision system to realize the positive atmosphere of national governance. Lastly, we shouldestablish the National Security Council to ensure that the national governance roll on the comprehensive safety orbit.

\section{References}

[1] Zhao Dong, Contrastive Study on the State Theory of Marxism and Liberalism, J., Journal of University of South China(Social Science Edition), 5(2011) 39-41.

[2] Dong Jinzhu, TheTheoryofGovernanceandtheStateIdeaofClassicalMarxism, Public Administration \& Law, 2(2016) 21-28.

[3] Li Muzi, TheNationTheoryofMarxandContemporary Significance, Liaoning University, D., 2011. 